\title{
表情が変化する着ぐるみ頭部システム
}

\section{Cartoon-Character Costume Head with Emotional Facial Expressions}

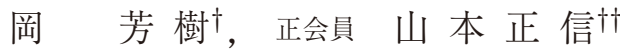

Yoshiki $\mathrm{Oka}^{\dagger}$ and Masanobu Yamamoto ${ }^{\dagger \dagger}$

\begin{abstract}
At a theme park or entertainment show, actors wearing a cartoon-character costumes entertain guests. Unfortunately, existing cartoon-character costumes have heads with a fixed facial expression. We propose a novel cartoon-character costume where the head is equiped with a web camera inside and display panel outside. When an actor wears the head, the web camera captures the face of the actor. Based on the pattern classification technique, the facial expression is classified into one of five categories of emotion: anger, joy, sadness, surprise and neutrality. For each category, a corresponding facial image is chosen from a bank of facial images of cartoon characters. The chosen image is depicted on the display panel as the face in real time. The new costume head enables the actor to communicate with audiences interactively and play the other characters immediately by changing the facial image bank.
\end{abstract}

キーワード：着ぐるみ，表情認識，画像処理，インタラクションシステム

\section{1. まえ がき}

テーマパークやイベントショーでは，様々な着ぐるみが 使用されているが，改良によりさらなる可能性を秘めてい る. 本研究は, 着ぐるみ自身が抱く感情の表現方法に着目 する，着ぐるみの多くは，自らの抱く感情の表現を身振り・ 手振りによる身体的動作で行わなければならない。そのた め, 着ぐるみによる動作を体得するには, 多くの労力と負 担が掛かってしまう。さらに，着ぐるみの容姿は固定され ており，1体 1 キャラクタしか演じられない. 演劇やイべ ントで複数のキャラクタが必要になると必要なキャラク夕 分の着ぐるみを用意しなければならない。増えたキャラク 夕分の演者の確保, 必要な着ぐるみの用意とさらに労力が 掛かってしまう。

これらの問題を解決する為に, 本研究では表情豊かな着 ぐるみを開発する。着ぐるみを着ている演者の表情を着ぐ るみの顔の表情に変換するシステムを提案する.このシス テムは，着ぐるみの顔自体を切り替え， 1 体の着ぐるみで

2011 年 12 月, SIGGRAPH ASIA 2011 Posters で発表

2012 年 3 月, 電子情報通信学会総合大会で発表

2013 年 6 月 28 日受付, 2013 年 9 月 27 日再受付,

2013 年 10 月 28 日採録

†新潟大学 大学院 自然科学研究科

（干 950-2181 新潟県新潟市西区五十嵐 2 の町 8050 番地, TEL 025-262-7387) ††新潟大学 工学部

（广 950-2181 新潟県新潟市西区五十嵐 2 の町 8050 番地, TEL 025-262-6709)

$\dagger$ Graduate School of Science and Technology, Niigata University

(8050, Ikarashi 2-no-cho, Nishi-ku, Niigata 950-2181, Japan)

$\dagger \dagger$ Faculty of Engineering, Niigata University

(8050, Ikarashi 2-no-cho, Nishi-ku, Niigata 950-2181, Japan)
複数の種類の表情豊かな着ぐるみが演じられる.

関連研究として, 石黒ら ${ }^{1)}$, 梶田ら ${ }^{2)}$ や高西ら ${ }^{3)}$ のヒュー マノイドロボット研究, または Garner Holt Productions ${ }^{4)}$

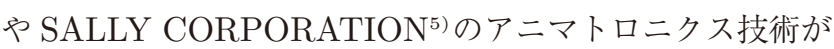
ある，表情や言語能力を持つヒューマノイドロボット，映 画やテーマパークアトラクションで用いられるアニマトロ ニクスは, 容姿, 能力共に人間に近い存在になっている。し かし，それらは離れた位置からの制御やプログラムによっ て動作する。そのため，人が媒体となって動作している着 ぐるみとは異なり，人とのコミュニケーションは間接的に なってしまう。

一方, 串山ら ${ }^{6)}$ は, 着ぐるみの容姿を維持したまま, 瞬き や口の開閉を行える着ぐるみを提案している。しかし，着 ぐるみの容姿が固定されているので，1体で複数のキャラ クタを演じることはできない.

提案する着ぐるみ頭部システムは，着ぐるみを着ている 演者のみから操作され, 観客との直接的なコミュニケーショ ンを実現する。製作する着ぐるみ頭部システムの構成は, 単純な構成とする。これは, 演者が熟練者や初心者の誰で あっても，着ぐるみ頭部システムの着用や使用に労力を掛 けないようにするためである。そして，着ぐるみの表情に はキャラクタ画像を用いる。着ぐるみの表情をロボットや ギミックを使用した写実的な表現より，マンガやアニメに 使用されるデフォルメが含まれる表現で着ぐるみの表情を 作成する，さらに，着ぐるみの表情として表示するキャラ ク夕顔を複数のキャラク夕分用意し，着ぐるみを着替えな くても複数のキャラクタを演じられるようにする。これに 
より，用意しなければならない着ぐるみの数を必要となる キャラクタ分の着ぐるみから，同時にステージ上で演技する 着ぐるみの最大数分までに削減できる。また，キャラク夕 顔の切り替えをステージ上で行えば一人芝居も可能となる.

本論文は，第 2 章で着ぐるみ頭部システムの構成につい て述べる。第 3 章では，着ぐるみの表情表示システムにつ いて述べる，第 4 章では，着ぐるみ頭部システムの動作実 験し，結果及び評価を示し，第 5 章で本論文をまとめる.

\section{2. 着ぐるみ頭部システム}

着ぐるみの容姿は，架空の人間，擬人化による生物や製 品が表現されている. 本研究は, 表情豊かな着ぐるみの開 発を目的としているので，着ぐるみの容姿の中でも着ぐる みの顔のみを開発対象にする。しかし，着ぐるみとして表 現するには，頭部だけでなく外見や衣装を含めた開発が今 後必要である，着ぐるみに表情を与える方法として，着ぐ るみの顔部分をディスプレイに置き換え，キャラクタ画像 を着ぐるみの表情としてディスプレイ上に表示する方法を とる。ディスプレイの使用は，着ぐるみとしての容姿や立 体的な顔の表現を損なうが，キャラク夕画像の表示，他の 機器との互換性や使用者の利便性を考慮すると, 適してい ると考えられる，さらに，着ぐるみの表情を豊かにするた めには, 多様な表情のキャラク夕画像に切り替える必要が ある。そこで，キャラク夕の表情画像の切り替えは，着ぐ るみを着ている演者の顔表情を利用する。着ぐるみを着て いる演者が顔パーツを動かし，作られた様々な表情を認識 し，分類して対応するキャラクタの表情画像へ切り替える システムを開発する。

着ぐるみの多くは，架空の人間，擬人化による生物や製品 になりきるために, 着ぐるみを着ている演者の容姿は隠さ れている，特に，演者の顔部分は着ぐるみの頭部に覆われ ているだけで，身体のように着ぐるみ衣装に覆われて，かつ 動作を行うのではないので，他の身体部位より制約が少な い.さらに，表情は日常生活でも使用されているので，特 別な訓練の必要なく使用できる。そして，演者の表情を使 用するので, 観客とのコミュニケーションを行う時に, 演者 自身の表情によって着ぐるみの表情が操作可能になり，円 滑なコミュニケーションを運べるようになる。

以上の観点から，本研究は着ぐるみの表情となるキャラ クタの表情画像を表示・切り替えるシステムを実現させる ために必要な機器が搭載された着ぐるみ頭部を製作した7)。 製作した着ぐるみ頭部を着用した様子を図 1 に示し，詳細 は以下で述べる。

\section{1 着ぐるみ頭部の製作}

プラスチック製の箱を頭部の土台とし，着ぐるみの表情 となるキャラクタの表情画像を表示する表示用デイスプレ イを箱前面に載せる。箱内部には, 確認用ディスプレイ, 演 者の表情を撮影する内部 Web カメラおよび演者の顔を照 らす LED 照明を載せる。確認用ディスプレイと着ぐるみ

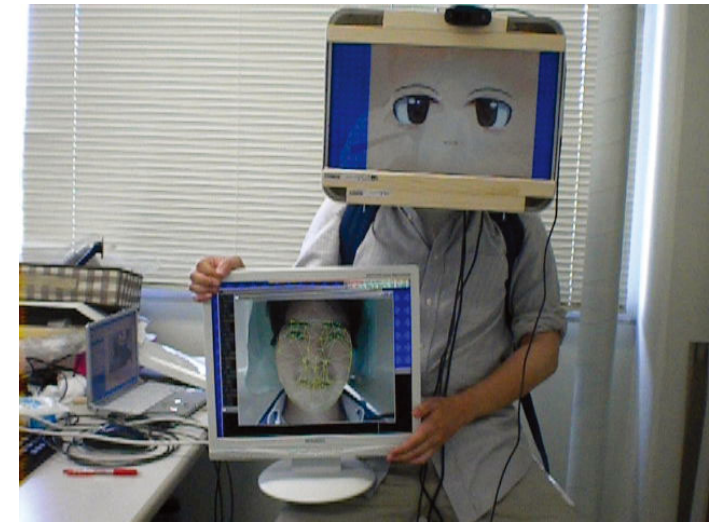

図 1 着ぐるみ頭部の着用

Wearing cartoon-character costume head.

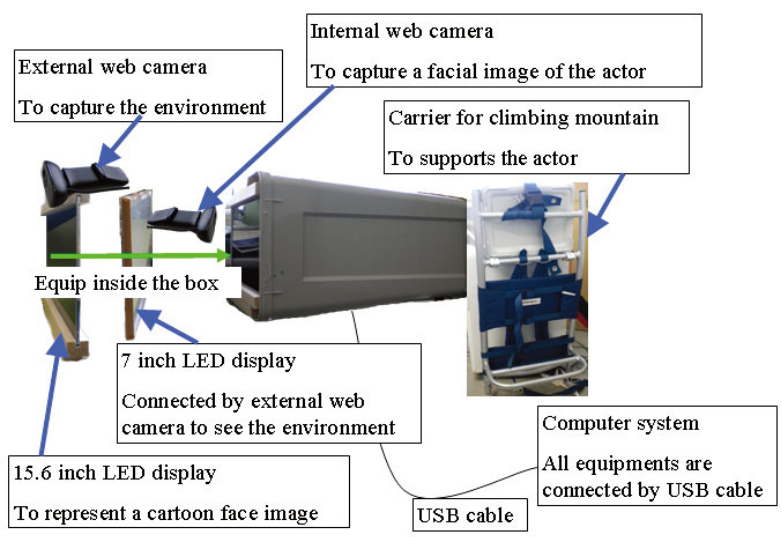

図 2 着ぐるみ頭部の構成図

Structure chart of cartoon character costume head.

頭部上段に搭載されている外部 Web カメラは,「目」の役 割を果たし，これを利用して演者は外の様子を確認できる ようになる，着ぐるみ頭部システムの視野は，確認用ディ スプレイの大きさと外部 Web カメラの解像度に依存する が，咞き穴のみでしか外の様子を確認できない従来の着ぐ るみよりは，広域で詳細な視野が手に入る。これらの機器 は，USB ケーブルを介して処理用パソコン (Intel core i7 870, RAM 3.2GB, WindowsXP) に接続されている。 こ の処理用パソコンは, 演者の表情を撮影, 表情認識を行い, 対応するキャラクタの表情画像を表示する処理を繰り返す. 確認用ディスプレイと外部 Web カメラは, 計算負荷を分散 するために処理用パソコンとは別の確認用パソコンに接続 されている。

現在，製作された着ぐるみ頭部は $4 \mathrm{~kg}$ と非常に重いため, 登山用キャリーを使用して重量による演者への負担を分散, 着ぐるみ頭部のバランス調節を行っている。これにより， 従来の演者の頭首のみで頭部支える着ぐるみより，製作し た着ぐるみ頭部の方が身体バランスを安全に保てるような る。最後に，搭載した機器と着ぐるみ頭部の構成を図 2 に 示す.

\section{2 着ぐるみ頭部の外・内装}

演者の表情を認識し, 分類して対応するキャラクタの表 


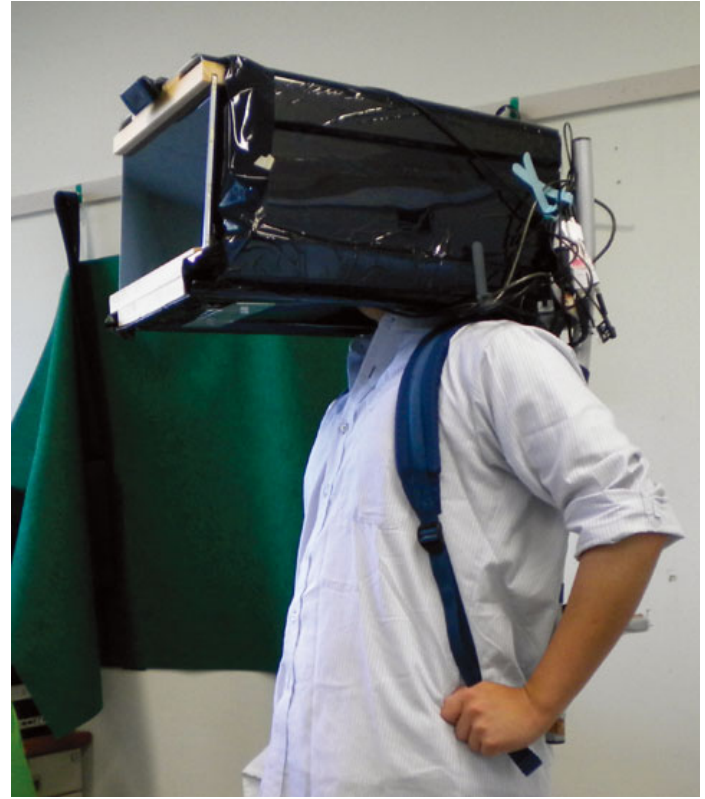

図 3 製作した着ぐるみ頭部の外観

Appearance of cartoon-character costume head.

情画像を着ぐるみの表情として表示するが，表情認識にお いて照明条件により認識率が左右されてしまう。着ぐるみ の活動場所は, 屋外, 照明機器が多数有るステージ上と周 囲の明るさが変動しやすい環境である。

製作した着ぐるみ頭部の全体を自動車用の遮光フィルム で覆う。600lx の室内で箱内部の明るさを測定したところ, 遮光フィルムなしの箱内部の明るさは $35 \mathrm{~lx}$, 遮光フィルム有 りの箱内部の明るさは $5 \mathrm{~lx}$ 以下であった. さらに, $1,000 \mathrm{~lx}$ の照明を箱へ当てたところ, 遮光フィルムなしの箱内部の 明るさは $45 \mathrm{~lx}$, 遮光フィルム有りの箱内部の明るさは $5 \mathrm{~lx}$ 以下に留まった。これにより, 遮光フィルムを用いること で照明の影響が軽減可能と判断される.

さらに，箱の内側には緑色の模造紙を貼り付け，グリー ンバックとし, 演者の表情をWeb カメラで撮影する時に, カラーバランスの問題が発生しないようにした。完成した 着ぐるみ頭部の外観を図 3 に, 内部を図 4 に示す。図 4 内 の中央に設置してあるのが内部 Web カメラ, 内部カメラ の後方には確認用ディスプレイがあり, 前方の映像が表示 されている，上方には，演者の顔を一定の明るさで照らす LED 照明が設置されている。

\section{3. 着ぐるみの表情表示システム}

第 2 章で製作した着ぐるみ頭部の前面にある表示用ディ スプレイに，着ぐるみを着ている演者の表情を認識し，対 応するキャラクタの表情画像を着ぐるみの表情として表示 する手法を開発した. 手法の流れは以下の (1)-(6)になる.

（1）内部 Web カメラから演者の表情を撮影

(2) faceAPI ${ }^{8)}$ による特徵点検出

（3）特徵点の位置, 変化量を測定

（4）測定されたデータから䦨值処理により表情の分類

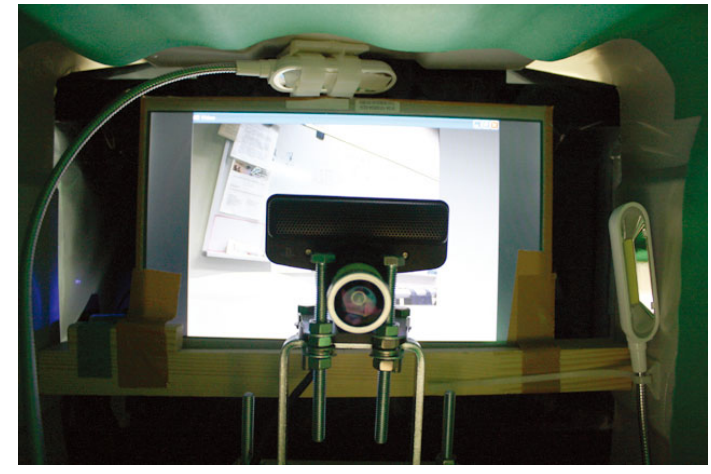

図 4 製作した着ぐるみ頭部の内部

The inside of the cartoon-character costume head.

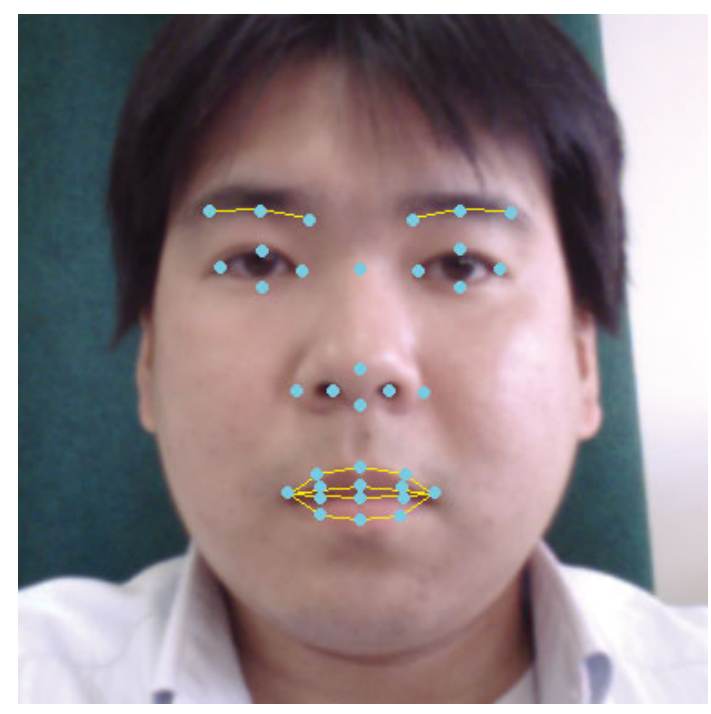

図 5 faceAPI で検出した特徵点

Feature points detected by faceAPI.

（5）分類結果より対応するキャラクタの表情画像を表示

（6）(1)の処理へ戻り, 処理の繰り返しへ

処理 (1)-(2) では, 内部 Web カメラで撮影された演者の 顔画像から, Seeing Mashines 社の faceAPI を用いて演者 の目，眉，口，鼻を特徴点で検出する。faceAPIを使用し て検出した特徽点を図 5 に示す.図 5 内の点は検出された 特徵点を示し, 眉上の線分は眉の形状を, 口上の線分は, 唇の領域を示している. 処理 (3)-(5) では, 検出した特徵 点の位置や変化を測定し，あらかじめ設定しておいた閾值 と比較して表情の分類を行う。閾值は，演者の表情から検 出した特徵点のデータによって設定でき, 表示したいキャ ラクタ画像と対応付けさせたい演者の表情も自由に設定で きる。今回は, Ekman ${ }^{9)}$ のACS (Facial Action Coding System）から, 分類する表情を, 喜び, 怒り, 悲しみ, 驚 きおよび無表情の 5 つとし，演者は以下に示す判定基準を 満たすように顔の動作を行うと，その表情が5つのいずれ かに分類される. 図 6 に判定基準を満たす演者の表情と対 応したキャラクタの表情画像の例を示す.

・喜び $\rightarrow$ 口両端を持ち上げ，上唇を平行にする

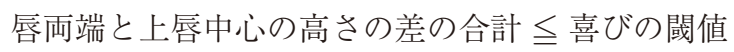

・怒り $\rightarrow$ 眉間にしわを寄せ，外側の眉両方を上げる 

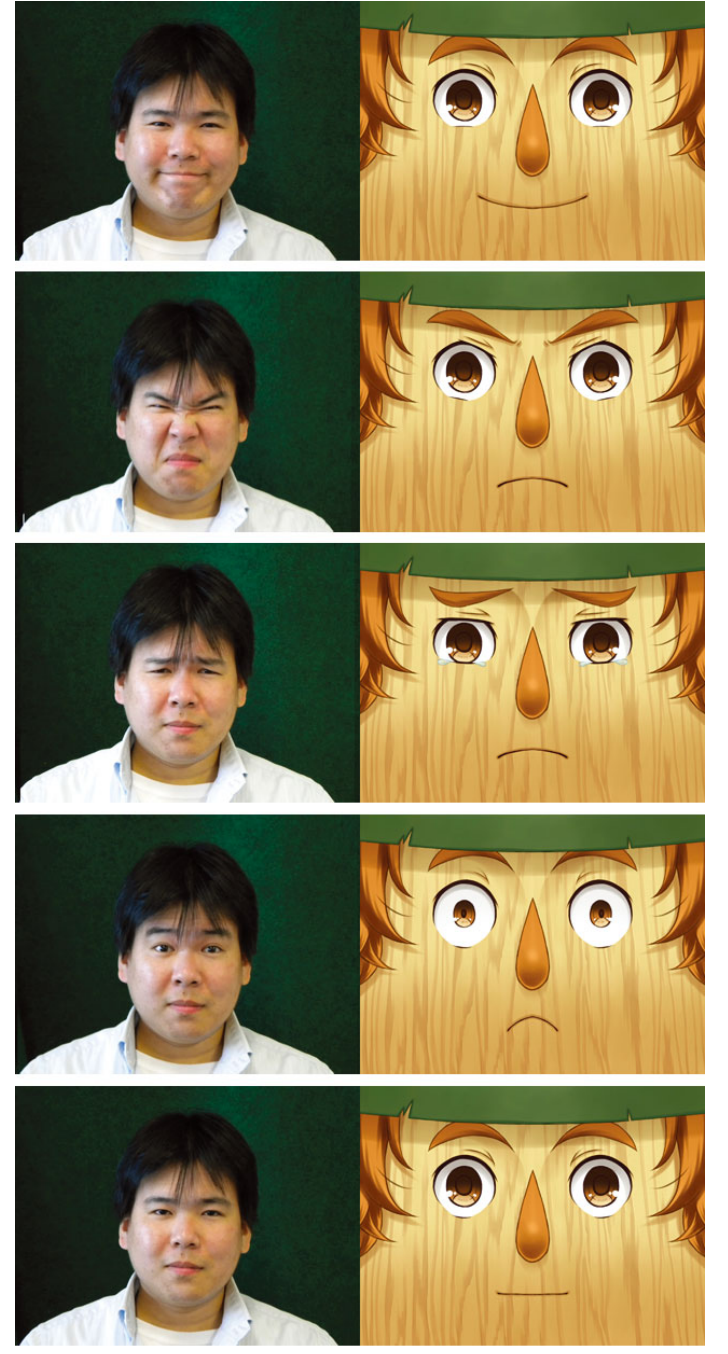

図 6 演者の表情と対応するキャラク夕の表情画像の例 (上か ら喜び, 怒り, 悲しみ, 驚き, 無表情)

Example: Actors facial expression and corresponding character image.(From above:Joy,Anger,Sadness,Surprise, Neutral faces)

各眉の眉間側と外側の高さの差の合計 $\geqq$ 怒りの闇值

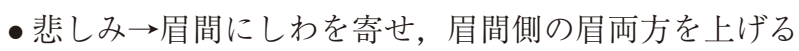
各眉の外側と眉間側の高さの差の合計 $\geqq$ 悲しみの閾値

・驚き $\rightarrow$ 眉全体を持ち上げ，目を見開く

各眉の中心と各目の上端の幅の合計 $\geqq$ 驚きの閾值

・無表情 顔パーツを動かさず，しわも作らない

他の表情の判定基準にすべて当てはまらない

表情認識手法として, 主成分分析 ${ }^{10)}$ やニューラルネット ワーク11)など様々な手法があるが，今回我々は特徵点の座 標値を設定した閾値で表情の分類を行う手法を選択した。 これは，処理時間を短縮するとともに，図 5 に示したよう に, 顔画像上に検出した特徵点が表示でき, 演者を変更し ても, 直感で閾值の確認と修正ができる利点があるからで ある。

表示するキャラクタの表情画像を多様にするために, 演 者の瞬きと口の開閉も認識, 分類に含め 表情 5 種類 $\times$ 瞬 き 4 種類 $\times$ 口の開閉 2 種類 の全 40 種類に分類する. 分類

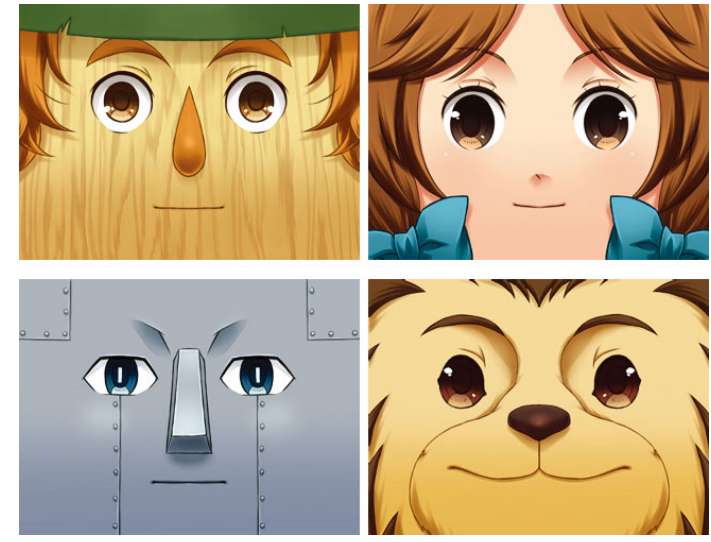

図 7 キャラクタ画像 (左上: かかし, 右上: ドロシー, 左下： ブリキの木こり, 右下：臆病なライオン)

The character image. (Upper left:Scarecrow,Upper right:Dorothy,Lower left:Tin Woodman, Lower right:Cowardly Lion)

された表情に対応するキャラクタの表情画像は，あらかじ め用意されており, 演者の表情を認識後, 即座にキャラク 夕の表情画像をディスプレイへ表示する. 図 9 にキャラク 夕の表情画像一覧を示す。

処理 (6)で, 処理の繰り返しに入り, 演者の表情の撮影, 特徵点検出，表情の分類，対応するキャラクタの表情画像 の表示の処理を続け，途中で演者が表情を変化させると着 ぐるみの表情であるキャラクタの表情画像が変化して表示 されるシステムとなる。

付加機能として, 複数の種類のキャラクタ用意しておき, 入力デバイスで表示したいキャラクタを選択すれば，1体 の着ぐるみで複数の種類のキャラク夕を演じられるシステ ムとなる。今回の実験用に用意したキャラク夕画像の一部 を図 7 に示す。図 7 のキャラク夕は, ライアン・フランク . ボーム著の「オズの魔法使い」に登場する，かかし，ドロ シー，ブリキの木こり抢よび臆病なライオンを表現してい る。入力デバイスはテンキーを用い，演者は片手でキャラ クタの切り替えを行う.

\section{4. 実 験・評 価}

製作した着ぐるみ頭部を着てシステムの稼動実験を行っ た．稼動実験中の演者の表情とキャラクタの表情画像の 1 コマを図 8 に示す．図 8 の右側は，今回製作した着ぐるみ を着ている演者であり，左側に演者の表情が表示されてい る，着ぐるみの演技をビデオ撮影し，着ぐるみ頭部システ ムの動作や処理速度, 認識率の評価を行った. ビデオ映像 は付録を参照 (ファイル名：Y_001.mp4).

着ぐるみの表情表示システムの評価は，演者の表情と認 識により表示されたキャラク夕の表情との整合性を複数回 の試行により判断する。試行結果と認識率を表 1 に示す. 表 1 の行は演者の表情で, 列は実際に表示されたキャラク 夕画像の表情である. 表情の分類に使用している要素数か ら考慮すると高い認識率を示していると言える。 


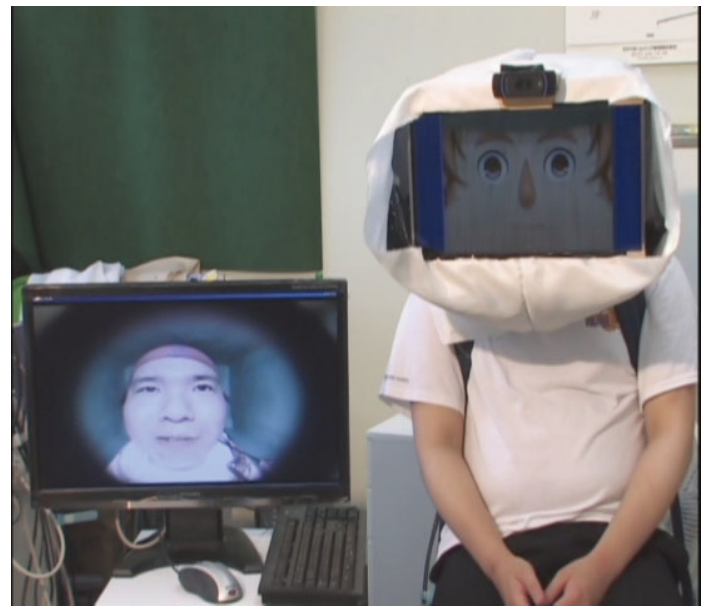

図 8 稼動実験

Operation experiment.

表 1 試行結果と認識率

Trial result and recognition rate.

\begin{tabular}{c|c|c|c|c|c|c|c}
\hline \hline & 総数 & 喜び & 怒り & 悲しみ & 驚き & 無表情 & 認識率 \\
\hline 喜び & 35 & 31 & 0 & 3 & 0 & 1 & 88.6 \\
\hline 怒り & 22 & 0 & 22 & 0 & 0 & 0 & 100 \\
\hline 悲しみ & 27 & 2 & 0 & 23 & 1 & 1 & 85.2 \\
\hline 驚き & 21 & 0 & 1 & 0 & 19 & 1 & 90.5 \\
\hline 無表情 & 17 & 0 & 1 & 0 & 1 & 15 & 88.2 \\
\hline \hline
\end{tabular}

図 9 には，キャラクタの表情画像一覧を示し，図 10 に 一覧表と対応させて表示したキャラクタの表情画像の遷移 図を示す。なお, 図 9 のキャラク夕の表情画像は左から喜 び，怒り，悲しみ，驚き，無表情の順で並べてある。図 10 は，表 1 で取得された試行結果とは異なる結果から作成さ れており，演者は意罒的に喜びの表情を作っていない.

演者の表情を認識してから対応するキャラクタの表情画 像が表示されるまで平均 $67 \mathrm{~ms}$ 要した。この程度の遅れで あれば，着ぐるみが観客との対話内容に違和感なく表情変 化行われると考えられる。

さらに，製作した着ぐるみを使用して，表情の有無による 印象を比較，評価した。着ぐるみに 1 枚のキャラク夕画像 を表示しながら芝居を行うビデオと, 演者の表情認識を行 いキャラク夕の表情画像が変化しながら表示される芝居を 行うビデオを大学生 256 名に見せ，どちらの着ぐるみに好 感を持てるか回答してもらった。なお，演者は同一人物，セ リフは同一にし，BGM 等の音響効果はビデオ内に含めてい ない. ビデオ映像は付録を参照 (ファイル名：Y_002.mp4 Y_003.mp4).

その結果，表情が変化する着ぐるみが良いと回答した者 が 167 名, 表情が変化しない着ぐるみが良いと回答した者 が 89 名であった。これから，「着ぐるみの表情の有無は与 える印象へ影響がない」という仮説を有意差検定で棄却す る ${ }^{12)}$. 仮説より，着ぐるみに表情が有る方が好感を持たれ る割合を $p_{0}=0.5$ とする。集団の総数は $n=256$, その うち，着ぐるみに表情が有る方に好感を持った学生の割合 は， $p=0.65$ である．有意水準を $5 \%$ とすると，

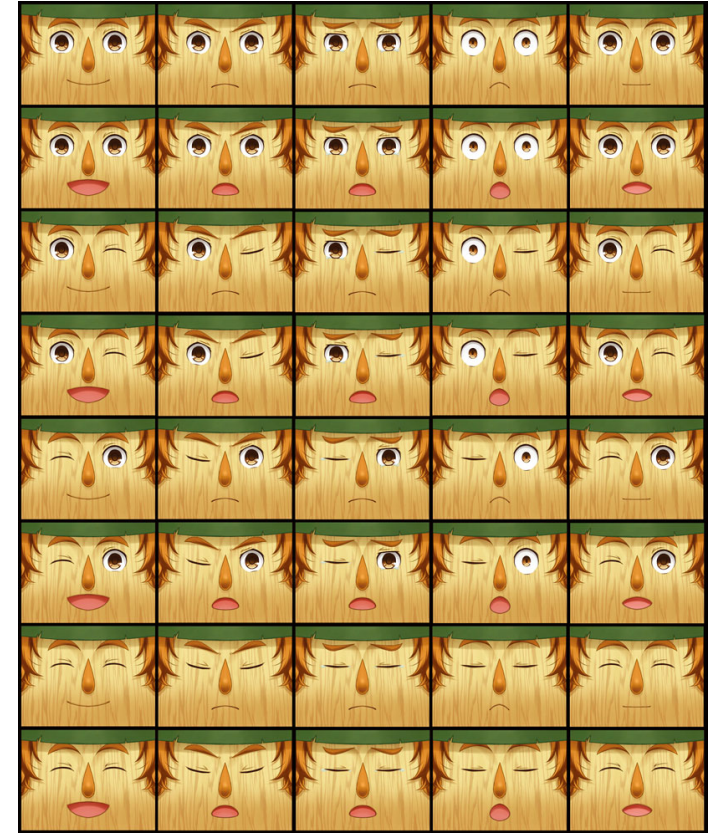

図 9 キャラク夕の表情画像一覧

List of facial expressions image of the character.

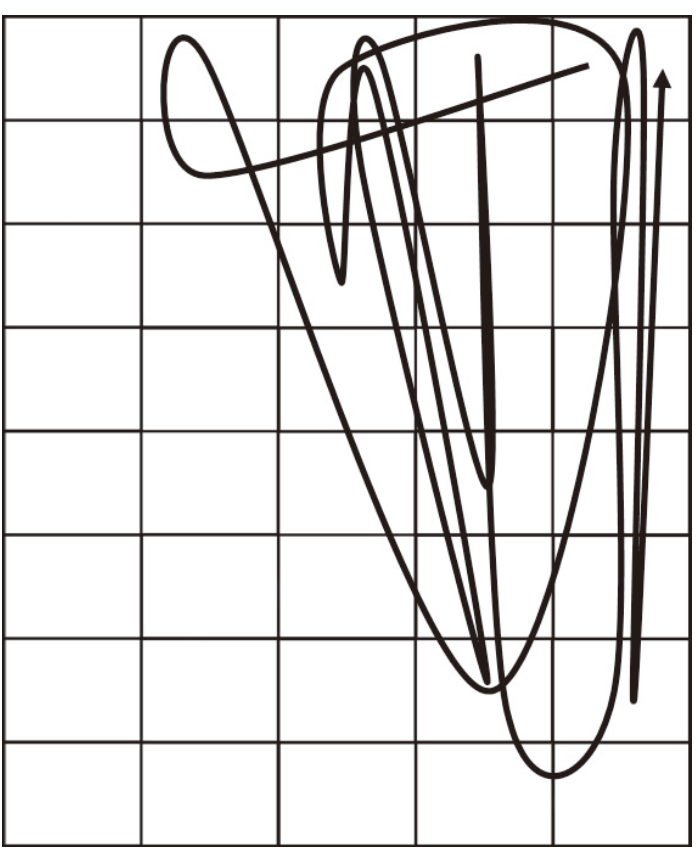

図 10 表示されたキャラクタの表情画像の遷移図 Transition diagram of represented facial expression image of the character.

$\frac{n p-n p_{0}}{\sqrt{n p_{0}\left(1-p_{0}\right)}}=5.74>1.96$

となるので，仮説は棄却される。よって，観客の半数以上 は着ぐるみに表情が有る方が好感を持つと考えられる。

さらに，製作した着ぐるみでコミュニケーション実験を 行った，着ぐるみと観客が 1 対 1 のじゃんけんを行い，着 ぐるみを着ている演者がじゃんけんの勝ち負けに反応でき るかを実験した。観客とのじゃんけん勝負を図 11 に示す。 図 11 内の手前側にある手は着ぐるみの対戦相手の手であ る。ビデオ映像は付録を参照 (ファイル名：Y_004.mp4). 


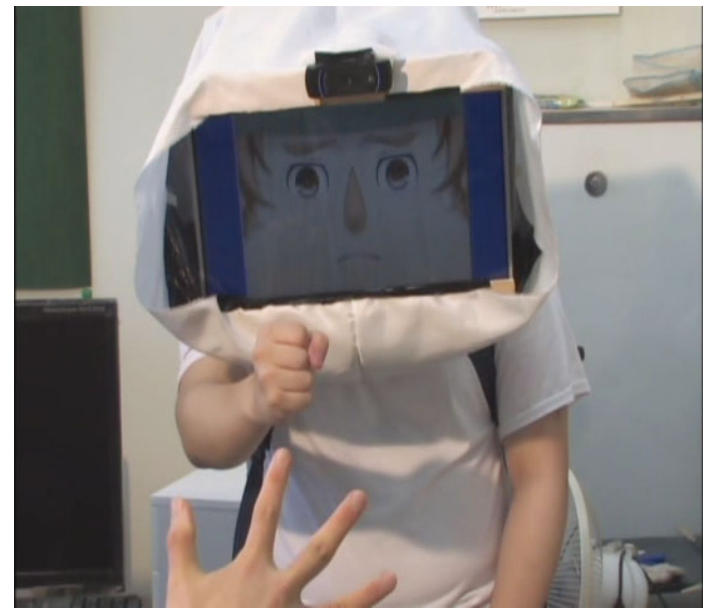

図 11 観客とのじゃんけん勝負

Rock-paper-scissors game with guest.

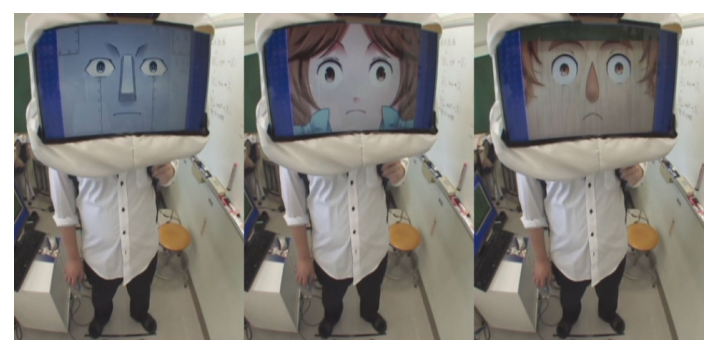

図 12 キャラク夕切り替え実験

Character switching experiment.

着ぐるみ側は勝った時は喜び，負けた時は悲しみ，あいこ の時は驚きの表情を瞬時に示し，じゃんけんは成立したと 言える.

最後に, 表示するキャラクタの表情画像を複数の種類の キャラクタ用意し，キャラクタの切り替え実験を行った。 キャラク夕切り替え実験の様子を図 12 に示す。演者は入 カデバイスとなるテンキーを右手に持ち，表情を維持した ままキー入力を行った. すると, 図 12 内の左から右へのよ うに表示されているキャラク夕の表情画像が種類の異なる キャラクタの表情画像へ切り替わった, しかし, 演者の表情 は変化していないので，分類されている表情は保持されて いる. ビデオ映像は付録を参照 (ファイル名：Y_005.mp4).

\section{5.むすび}

本論文では, 着ぐるみ頭部に機器を搭載し, 演者自身が自 由に着ぐるみの表情を変化させるシステムを提案した。着 ぐるみの表情表示システムの動作速度の計測, 認識率の算 出, 製作した着ぐるみ頭部システムの印象を評価し，有効 性を示した。また, 観客とのじゃんけん勝負を行い, 着ぐ るみ頭部システムを通してのコミュニケーションが成立し た。ささらに、今まで 1 体 1 キャラクタであった着ぐるみを 1 体で複数の種類のキャラク夕を扱えるようにした。

今後は, 着ぐるみ頭部の開発のみではなく, 着ぐるみ全体 を含めた開発・改良を行いたい。着ぐるみのキャラクタや 表情の切り替えだけでなく，衣装を含めた切り替えシステ
ムについても考えていく．さらに，実地に赴き，実際に人 と触れ合い，評価を受けてみたい。そして，今回は取り入 れていなかったキャラク夕の表情画像のスムーズな切り替 え ${ }^{13)}$ を取り入れ，さらなる着ぐるみの可能性を見出したい.

\section{〔文献〕}

1）塩見昌裕，坂本大介，神田崇行，石井カルロス寿憲，石黒浩，萩田紀博： “半自律型コミュニケーションロボットの開発”, 信学論, J92-A, 11, pp. $773-783$ (2009)

2) 梶田秀司, 中野倫靖, 後藤真孝, 松坂要佐, 中岡慎一郎, 横井一仁：“ヒュー マノイドロボットの自然な歌唱動作生成”，第 29 回日本ロボット学会 学術講演会, RSJ2011AC1J3-2 (2011)

3）三輪洋靖，高信英明，高西淳夫：“人間との情緒的コミュニケーション を目的とした人間形頭部ロボットの開発 (第 1 報, 表情表出機構と視覚 系を構築)", 日本機械学論, C 編 68(675), 3355-3360 (2002)

4) Garner Holt Productions :

http://www.garnerholt.com/ghp-inc/products-services/animatronics.aspx

5) SALLY CORPORATION :

http://sallycorp.com/animatronics/life-like/

6) Rika Shoji, Toshiki Yoshiike, Yuka Kikukawa, Tadahiro Nishikawa, Taigetsu Saori, Suketomo Ayaka, Tetsuaki Baba, Kumiko Kushiyama: "mimicat:Face input interface supporting animatronics costume performer's facial expression", SIGGRAPH 2012 Posters(2012)

7) Yoshiki Oka, Tomoaki Kida, Masanobu Yamamoto: "A CartoonCharacter Costume with Facial Expression", SIGGRAPH ASIA 2011 Posters(2011)

8) Seeing Machines : "faceAPI", http://www.seeingmachines.com/product/faceapi/

9) Paul Ekman: "The facial action coding system", Consultion Psychologists Press (1978)

10）赤松茂：“人による認知特性と整合した顔表情認識のための特徵表現法”, 信学技報, PRMU2002-205 pp. 25-32 (2003)

11）渡部徹, 石原由一朗, 岸田悟, 徳高平蔵: “顔画像の表情認識問題における 階層型ニューラルネットワークの適用”，信学技報, NC97-8 pp. 57-62 (1997)

12）和達三樹, 十河清：“キーポイント確率・統計”, 岩波書店 (2000)

13）岡芳樹, 山本正信：“スムーズに表情が変化する着ぐるみシステムの開 発”, 信学総大, Mar.21,2012 D-12-68 (2012)

〈付

録〉

\section{A. 実験時の動画について}

今回行われた実験の様子を以下のアドレスで示す. http://www.vision.ie.niigata-u.ac.jp/oka_yoshiki/

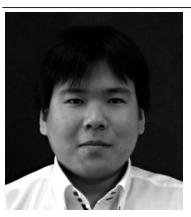

岡势芳樹 2011 年, 近畿大学大学院システム工 学研究科修士課程修了. 現在, 新潟大学大学院自然科学 研究科博士課程に在学中. バーチャルリアリティに関す 石研究に従事.

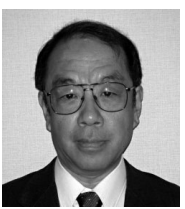

やまも本 整す信 1973 年, 九州工業大学工学部制御工 学科卒業. 1975 年, 東京工業大学大学院修士課程修了. 同年，電子技術総合研究所入所. 現在，新潟大学工学部 情報工学科教授.コンピュータビジョン、コンピュータ グラフイックス等の研究に従事. 工学博士. 正会員. 